\title{
Seed Piece Spacing Adjustment for Florida Chipping Potato ${ }^{1}$
}

\author{
Fernanda Souza Krupek, Steven A. Sargent, Peter J. Dittmar, and Lincoln Zotarelli²
}

The analysis presented in this publication was extracted from a series of field trials conducted during the spring seasons of 2013, 2014, and 2016 looking at improved potato plant arrangement in the field by adjusting seed piece spacing for Florida growing conditions. The effects of seed piece spacing on total and marketable tuber yield, tuber size distribution, and physiological disorders were evaluated for three chipping potato cultivars: Atlantic, Harley Blackwell, and Elkton. The second objective of this document was to present a partial budget analysis to determine the net return of in-row spacing treatments. The calculation was based on seed and freight costs, and yield as a result of seed piece spacing.

Seed spacing directly affects crop revenue because the number of potato seeds planted determines the final plant population density. The selected seed piece spacing will optimize seed and freight cost while increasing or maintaining marketable yield. With the recent increase of potato production costs and lower prices paid for produce, the optimization of seed piece spacing would be of interest to Florida potato growers who intend to maximize their profits while supplying the US potato market in the crop off-season.

\section{Current Seed Piece Spacing Guidelines}

The number of plants per unit of area, termed plant population, as well as seed piece spacing, meaning plant arrangement, are used interchangeably in many scientific reports. Based on seed piece spacing studies already conducted, it is possible to predict the response of seed piece spacing on potato yield per unit of area for Florida production system. Typically for a given potato cultivar, as we increase the plant density, the total yield also increases. Because of the interplant competition for available nutrients, water, space, and sunlight, a plateau is reached in terms of maximum yield. At this peak, space and plant nutrition constraints limit potato plants from producing more or larger tubers, which means increasing the number of plants per area cannot increase tuber yield. As a broad assumption, we did not take into consideration that some cultivars can differ in their ability to compensate for wider gaps as the plant population is reduced.

The Florida guidelines for in-row seed spacing ranges from 5 to 10 inches, which favors planting development due to climate, soil, and cultivar characteristics (Zotarelli et al. 2016). The reason for a broad range of seed piece spacing is the variability of spacing between-rows and soil characteristics of Florida potato production areas. The distance between rows in Florida ranges from 36 to 42 inches depending upon soil drainage capacity. Well-draining soils

1. This document is HS1317, one of a series of the Horticultural Sciences Department, UF/IFAS Extension. Original publication date May 2018. Visit the EDIS website at http://edis.ifas.ufl.edu.

2. Fernanda Souza Krupek, graduate student; Steven A. Sargent, professor; Peter J. Dittmar, assistant professor; and Lincoln Zotarelli, assistant professor; Horticultural Sciences Department, UF/IFAS Extension, Gainesville, FL 32611. 
allow the narrowest spacing between rows. Although potato growers have adopted this general recommendation, there is no information available about the optimum seed piece spacing for Florida growing condition in which marketable yield and economic return are taken into account. Furthermore, market requirements and inspection for chipping, table stock (fresh market), or processing potatoes consider different parameters as quality factors, many of them directly affected by seed piece spacing. However, current Florida seed piece spacing guidelines are not distinguished by potato type.

Processed potatoes remain a key product in the American diet, whether purchased as frozen French fries, reconstituted dehydrated product, or potato chips. Potato production in Florida mainly supplies chipping potato. Tuber quality requirements for chipping potato do not necessarily consider a good external appearance; however, the dry matter content and internal quality affect the overall processing quality. In addition, good skin set will reduce water losses during transport and storage. Florida growing conditions are unsuitable for potato seed production; hence, seeds are previously ordered from far northern production areas and shipped to Florida prior the season. Because seed costs (seed and freight costs) are one of the key elements included in operating pre-harvest costs, a balance among agronomic yield and quality, cost of production, and economic return is the starting point for a successful potato production.

\section{Performance of Seed Piece Spacing Study in Florida}

\section{Yield and tuber size distribution}

Three chipping potato cultivars grown in Florida, Atlantic, Harley Blackwell, and Elkton, were evaluated for in-row seed piece spacing of $4,6,8,10$, and 12 inches during spring seasons of 2013, 2014, and 2016. The 2013 and 2014 data were combined because similar responses to seed piece spacing were observed due to similar weather conditions. Total and marketable yield increased as in-row seed piece spacing decreases (higher plant density) in 2013 and 2014, while widening seed piece spacing resulted in an increase in tuber yield in 2016. The average marketable yield from the 2013 and 2014 season was 125, 110, 100, 109, and 95 hundred weight (cwt) per acre for in-row seed piece spacing of $4,6,8,10$, and 12 inches, respectively. Conversely, the average marketable yield in 2016 was $89,117,154,159$, and $176 \mathrm{cwt}$ per acre for in-row seed piece spacing of $4,6,8,10$, and 12 inches, respectively (Table 1).
All trials were conducted with a 40 -inch distance between rows. Tuber marketable yield (size A-above 1.88" diameter) at 8 -inch seed piece spacing (the industry standard) was lower than the 10-inch seed piece spacing for all three years (Table 1). All cultivars tested performed similarly under each seed piece spacing.

Despite the difference in yield responses across years, the proportion of small and unmarketable tubers (tuber sized B and $C$, and culls) increased at narrower seed piece spacings whereas large-sized tubers (A2, A3, and A4) increased with a decrease in plant density in all three years of study. At low plant densities, cultivars compensate for increased space by producing bigger tubers because more space is available for tuber bulking than at high plant density (Figure 1). Reduced interplant competition at low plant density also resulted in increased production of larger tubers in russet cultivars such as Alturas, Russet Norkotah, and Ranger Russet (Bohl et al. 2011). On average, as seed piece spacing increases from 4 to 12 inches, the proportion of unmarketable tubers decreases from $42 \%$ to $31 \%$ of the total yield, while the proportion of large tubers increases by $11 \%$ of the total tuber yield (Figure 1). Marketable tubers comprised a significant proportion of tuber total yield. In 2013, about $80 \%$ (114 cwt/acre) of tuber total yield were classified between A1 and A4 (>1.90" diameter), while in 2014 and 2015 the proportions were $61 \%$ (102 cwt/acre) and 53\% (139 cwt/acre), respectively.

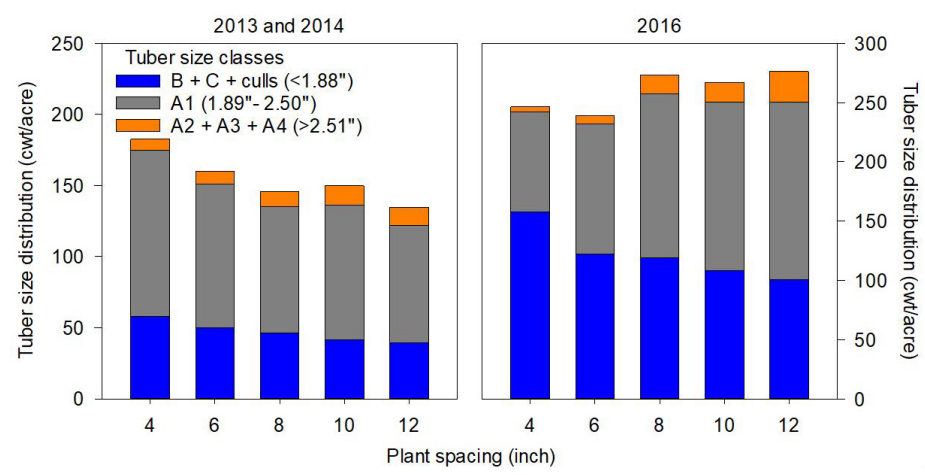

Figure 1. Tuber size distribution potatoes planted at 4, 6, 8, 10, and 12 inches in-row seed piece spacing in the spring of 2013, 2014, and 2016. Note: all trials were conducted using a 40-inch distance between rows.

\section{Internal quality and specific gravity}

The current study has shown that, under Florida growing conditions, plant arrangement has no effect on internal tuber disorders such as brown center, hollow heart, and internal heat necrosis. Such disorders can compromise chip color and appearance, which are important quality parameters during potato processing. Potato cultivars respond differently to internal disorders given their genetic 
background. Atlantic has greater incidences of hollow heart and brown center than Elkton and Harley Blackwell.

Specific gravity is an important factor for the processing industry in terms of potato chips, fry quality, and efficiency (amount of potato chips processed from raw potatoes). Specific gravity (potato solids content) was not consistently affected by plant density in this study.

\section{Budget analysis}

Seed piece spacing directly affects the cost of the seed (amount of seeds ordered) and indirectly affects operating expenses such as handling, storage, cultural practices, and transportation. Regardless of any atypical growing conditions affecting plant emergence and establishment, a final plant population of 39,600 plants/acre may be achieved with the 4-inch seed piece spacing, while the wide spacing of 12 inches gives a maximum of 13,068 plants/ac. Plant spacing imposes a limit on the amount of seed required for planting, which directly affects grower costs. The number of pallets ordered depends on the amount of seed potato required for a given plant arrangement in the area. For the regular 2-ounce seed piece, spacing selected from 4 to 12 inches results in a seed order ranging approximately from 50 to $16 \mathrm{cwt}$ per planted acre, respectively (Table 1). If growers intend to ensure a high final plant population, more potato seeds are required per unit area. For narrower seed piece spacing, the operating preharvest costs increase proportionally because growers have to buy more seeds, which increase shipping, transportation, and storage costs. In case of 4 or 6 inches, the narrowest seed spacing, production might become less cost-effective due to potato seed expenditures.

Net revenue estimated for each seed piece spacing is shown in Table 1, in which variable contract/selling prices for tuber marketable size (above 1.88-inch diameter) are taken into account. The calculation was based on 13,068 linear feet per acre, $2 \mathrm{oz}$ per seed piece, and seed cost of $\$ 31 / \mathrm{cwt}$ of seeds.

The freight cost is an important component of total seed cost and varies from load to load (pick-up and delivery location, potato variety, and package size ordered). For the commercial seed loads shipped to North Florida in 2016, the grower's cost was $\$ 7.75$ per cwt with one pick-up and delivery location. Considering a 100 -acre commercial farm, the seed piece spacing of $4,6,8,10$, and 12 inches the cost for transportation would be approximately $\$ 38,000$, $\$ 25,000, \$ 19,000, \$ 15,000$, and $\$ 12,000$, respectively. This means that from the lowest to the highest plant density, seed piece spacing selection would impact more than $\$ 25,000$ grower's net revenue gain (\$250/acre). Since fuel prices have remained relatively stable over recent years, it is expected these rates would be similar in the next potato seasons, which makes this study applicable to future circumstances.

\section{Determining the Optimum Seed Piece Spacing}

What is the optimum potato seed piece spacing for Florida chipping potato cultivars? First of all, potato growers should consider their production budgets and the available resources to invest, considering that potato seed accounts for approximately $10 \%$ of the overall cost of production in Florida added to the shipping costs. The budget analysis conducted based on three seasons of data considered marketable yield, cost of seed, and net revenue determined by contract/selling prices paid to the growers. The analysis demonstrated that the 10 -inch spacing provided a greater net revenue return than 8-inch spacing, which is the standard spacing for the chipping industry. The 12-inch spacing showed the greatest economic return in 2016; however, this response was not consistent across all the years studied. When potatoes were grown under less favorable weather conditions, 12-inch spacing tended to yield lower than 10-inch spacing, and increasing spacing interval from 10 to 12 inches was disadvantageous.

Considering there were no significant differences in total or marketable yield between the 8- and 10-inch spacing in this study, it is justifiable to suggest that net revenue can be increased by adjusting seed spacing from 8 to 10 inches without negatively impacting yield. From an operating costs' point-of-view, freight costs are reduced by $\$ 40 /$ acre and seed costs are reduced by $\$ 158 /$ acre by switching to 10 -inch spacing. The study also suggests that the 10 -inch seed piece spacing does not negatively affect the quality of chipping potatoes; thus, the profit gains support the spacing change.

The results from this study can be incorporated into existing management strategies for potato production in Florida. For example, reducing the amount of seed ordered by selecting a 10-inch, in-row seed piece spacing not only results in the same expected yield from 8 inches, but also reduces operating expenses with handling, storage, cultural practices, and transportation. This study provides field- and economic-based insights into the seed piece spacing selection, which supplies basic information for further strategies that best balance the cost production and economic return. 


\section{More Information Regarding Potato Seed Piece Spacing}

Bohl, W.H., J.C. Stark, and C.S. Mcintosh. 2011. "Potato seed piece size, spacing, and seeding rate effects on yield, quality and economic return." Amer. J. Potato Res. 88: $470-478$.

Krupek, F.S., C.T. Christensen, C.E. Barrett, and Zotarelli, L. 2017. "Seed piece spacing for spring chipping potato cultivars in Florida." HortScience, 52: 230-235.

2017 Potato Statistical Yearbook. 2017. National Potato Council. Retrieved from https://www.flipsnack.com/ nationalpotatocouncil/2017-potato-statistical-yearbookfinal.html (Accessed 03 Feb. 2018).

The Maine Potato Lady. "Ordering information - Shipping charts." 12 Feb 2018. Retrieved from https://www.mainepotatolady.com/productcart/pc/viewContent.asp?idpage $=1$

Zotarelli, L., P.J. Dittmar, P.D. Roberts, and S.E. Webb. 2016. "Potato production," p. 233-251. In: Vegetable production handbook of Florida, J. Dittmar, J.H. Freeman, and G.E. Vallad (eds.). Lincolnshire, IL: Vance Publishing. 
Table 1. Marketable yield, seed and freight costs, and net revenue for 2-oz seed piece for Atlantic, Elkton, and Harley Blackwell planted at 4-, 6-, 8-, 10-, or 12-inch seed piece spacing in 2013, 2014 (combined), and 2016 growing seasons in Hastings, FL.

\begin{tabular}{|c|c|c|c|c|c|c|c|}
\hline \multirow{2}{*}{$\begin{array}{c}\text { Seed piece } \\
\text { spacing } \\
\text { inches }\end{array}$} & \multirow{2}{*}{$\begin{array}{c}\text { Total yield } \\
\text { cwt/ac }\end{array}$} & \multirow{2}{*}{$\begin{array}{c}\text { Marketable yield } \\
\text { cwt/ac }\end{array}$} & \multirow{2}{*}{$\begin{array}{c}\text { 2-oz seed } \\
\text { cwt/ac }\end{array}$} & \multirow{2}{*}{$\begin{array}{c}\text { Seed cost } \\
\text { \$/ac }\end{array}$} & \multirow{2}{*}{$\begin{array}{c}\text { Freight } \operatorname{cost}^{\mathrm{x}} \\
\text { \$/ac }\end{array}$} & \multicolumn{2}{|c|}{$\begin{array}{c}\text { Estimated net revenue }{ }^{y} \text { (\$ per } \\
\text { cwt) }\end{array}$} \\
\hline & & & & & & $\$ 11$ & $\$ 13$ \\
\hline \multicolumn{8}{|c|}{$2013 / 2014$} \\
\hline 4 & 183 & 125 & 50 & 1,535 & 384 & (\$544) & (\$294) \\
\hline 6 & 160 & 111 & 33 & 1,013 & 253 & $(\$ 51)$ & $\$ 171$ \\
\hline 8 & 146 & 100 & 25 & 767 & 192 & $\$ 141$ & $\$ 341$ \\
\hline 10 & 150 & 109 & 20 & 610 & 153 & $\$ 436$ & $\$ 654$ \\
\hline 12 & 135 & 96 & 16 & 506 & 127 & $\$ 418$ & $\$ 609$ \\
\hline \multicolumn{8}{|c|}{2016} \\
\hline 4 & 246 & 89 & 50 & 1,535 & 384 & $(\$ 940)$ & $(\$ 762)$ \\
\hline 6 & 239 & 117 & 33 & 1,013 & 253 & $\$ 21$ & $\$ 255$ \\
\hline 8 & 273 & 154 & 25 & 767 & 192 & $\$ 735$ & $\$ 1,043$ \\
\hline 10 & 267 & 158 & 20 & 610 & 153 & $\$ 975$ & $\$ 1,291$ \\
\hline 12 & 276 & 176 & 16 & 506 & 127 & $\$ 1,303$ & $\$ 1,655$ \\
\hline
\end{tabular}

